九州大学学術情報リポジトリ

Kyushu University Institutional Repository

\title{
Characteristics of the Rice Marketing System in Cambodia
}

Hang, Chuon Chamrong

Graduate School of Bioresource and Bioenvironmental Sciences, Kyushu University

Suzuki, Nobuhiko

Faculty of Agriculture, Kyushu University

https://doi.org/10.5109/4681

出版情報：九州大学大学院農学研究院紀要. 50 (2)，pp.693-714，2005-10-01. Faculty of Agriculture, Kyushu University

バージョン：

権利関係 : 


\title{
Characteristics of the Rice Marketing System in Cambodia
}

\author{
HANG CHUON Chamrong ${ }^{1 *}$ and Nobuhiro SUZUKI \\ Laboratory of Quantitative Analysis of Agribusiness Organization, Division of Industrial \\ Organization of Agribusiness, Department of Agricultural and Resource Economics \\ Faculty of Agriculture, Kyushu University, Fukuoka 812-8581, Japan \\ (Received June 30, 2005 and accepted July 26, 2005)
}

\begin{abstract}
Although Cambodia achieved an overall self-sufficiency in rice supply in 1995, many obstacles such as poor roads and illegal fee collections by government officials increase the marketing costs and create distribution barriers to deficit areas. Farmers' income remains very low because they have poor bargaining power for rice price formation due to limited chances to meet buyers and not much information of agro-product prices available. Some collectors dominate the marketing by lending money, selling seeds and fertilizer on credit to the majority of farmers. Farmers have almost no other options once they borrowed money. In addition, an unimproved rice quality standard causes no incentive for improvements in rice quality. Creating an open paddy market, where many buyers and sellers gather for their paddy transaction, will provide more opportunities for farmers to see better buyers. Also, such markets will form an open-index-price reflecting the supply/demand situation of the production area.
\end{abstract}

\section{INTRODUCTION}

Cambodia is located in the southeast of Indochina, between $10^{\circ} \mathrm{N}$ and $15^{\circ} \mathrm{N}$ in tropical zone. The total area is $181,035 \mathrm{~km}^{2}$ with fertile land and abundant water resources in the Mekong river system, where $80 \%$ of working population engaged in agriculture in 1996, and the agricultural sector generated 36.9\% of GDP (Gross Domestic Product). Thus, Cambodia is referred to as a farming nation. The total GDP was 3.7 billion US\$ and the growth rate of GDP was about $4.5 \%$ in 2002 . GNI (Gross National Income) per capita, however, was still 280 US $\$$ in 2002 . Population is 11.43 million in $1998,84 \%$ of which live in farm village areas, and $40 \%$ of them are poverty group in 1997 . Rice production occupies $86 \%$ of cultivating areas for food production and $17 \%$ of GDP in 2000 . Rice covers $75 \%$ of calorific values for the entire food in Cambodia, and the percentage is the highest among the Southeast Asian countries. Per capita consumption of milled rice is $143.0 \mathrm{~kg}$ (2001-2003), which is 2.2 times more than $64.5 \mathrm{~kg}$ in Japan.

The main target of the Second Socio-Economic Development Plan (SEDDPI) and the Agricultural Development Plan (2001-2005) is reduction of poverty through the necessary actions: 1) Strengthen the national food security program, 2) Promote commercial transaction of surplus agro-production, and 3) Improve quality of agro-products. The entire nation of Cambodia reached at a self-sufficient condition of rice. However, the agricultural marketing system is still indigested due to a liberal un-bringing policy and

\footnotetext{
1 Laboratory of Quantitative Analysis of Agribusiness Organization, Division of Industrial Organization of Agribusiness, Department of Agricultural and Resource Economics, Graduate School of Bioresource and Bioenvironmental Sciences, Kyushu University

* Corresponding author (E-mail: hchamrong@hotmail.com)
} 
unchanged/undeveloped system. It caused: 1) Farmers have poor bargaining ability for rice price formation due to limited chances to meet buyers and not much information of agro-product prices available, etc. to be finally obliged to accept a low selling price, 2) There is a large regional difference of rice prices due to not enough price information among rice traders, 3) An unimproved rice quality standard causes no incentive for improvements in rice quality.

Under these circumstances, the Royal Government of Cambodia requested the Government of Japan to conduct a feasibility study on establishment of the Open Paddy Market (OPM) in Cambodia. The final goal of our analysis is to evaluate the effectiveness of the OPM in Cambodia. How will the OPM improve the problems described above? In order to examine it, at first we should recognize in detail what are the problems and what should be improved in the rice marketing system in Cambodia. This report is the first step of our analysis on the OPM evaluation, and the objective of this report is to specify the characteristics and problems of the rice marketing system in Cambodia.

\section{RICE SUPPLY/DEMAND SITUATION}

In Cambodia, 12 years have passed since economic recovery commencement. The rice production and marketing system is basically under a liberalized condition.

Table 1. Balance of rice by province (ton), 2003-2004

\begin{tabular}{lrrr}
\hline \multicolumn{1}{c}{ Province } & Paddy Production & Demand of Rice & Balance (Milled Rice) \\
\hline Banteay Mean Chey & 323,163 & 107,592 & 72,345 \\
Battambang & 446,359 & 140,115 & 108,418 \\
Kampong Cham & 484,551 & 261,793 & 8,005 \\
Kampong Chhnang & 186,336 & 71,708 & 32,044 \\
Kampong Speu & 181,154 & 102,097 & $\boldsymbol{\nabla} 1,231$ \\
Kampong Thom & 169,012 & 95,652 & $\mathbf{\nabla}, 546$ \\
Kampot & 285,966 & 85,090 & 74,136 \\
Kandal & 304,376 & 175,094 & $\mathbf{\nabla}, 617$ \\
Koh Kong & 12,527 & 26,262 & 19,287 \\
Kratie & 95,334 & 46,489 & 6,593 \\
Mondulkiri & 19,260 & 5,892 & 4,832 \\
Phnom Penh City & 21,571 & 181,951 & 169,940 \\
Preash Vihear & 40,906 & 21,222 & 1,554 \\
Prey Veng & 639,452 & 148,101 & 207,946 \\
Pursat & 135,678 & 60,279 & 15,267 \\
Rotanakiri & 47,052 & 16,826 & 9,373 \\
Siem Reap & 256,795 & 120,301 & 22,682 \\
Preash Sihanouk Town & 28,376 & 28,883 & $\mathbf{\nabla}$ \\
Stueng Treng & 33,950 & 14,462 & 4,441 \\
Svey Rieng & 314,336 & 76,144 & 98,878 \\
Takeo & 616,757 & 127,238 & 216,172 \\
Otdar Mean Chey & 59,382 & 13,644 & 19,420 \\
Kep Town & 7,390 & 5,233 & $\mathbf{\nabla}, 118$ \\
Pailin Town & 1,274 & 4,496 & $\mathbf{\nabla 8 6 , 4 9 6}$ \\
Total & $\mathbf{4 1 0 , 9 5 7}$ & $\mathbf{1 , 9 3 6 , 5 6 5}$ & \\
Sal & & \\
\hline
\end{tabular}

Source: Statistics of MAFF 
Marketing system itself is still immature. On the other hand, development of the rice industry will contribute a great deal to vitalization of the national economy, poverty alleviation of a majority of population and a part of demobilization.

There was a deficit situation of rice under the state-planned economy. Due to transition into a market economy, rice supply has been kept a surplus situation since 1995, taking no account of rice quality as shown in Table 1 . Meanwhile the poverty situation has unchanged.

Since Cambodia achieved the rice self-sufficiency in 1995, annual paddy production has been in the range of 3.4-4.0 million tons. According to the 2003/2004 food balance data (MAFF, Agricultural Statistics 2003/2004), the total provincial surplus amount is 902,106 tons (milled rice), the total provincial deficit is 215,610 tons, and the national surplus is 686,496 tons. Due to lack of adequate statistical data on farmer's gross sales quantity, it is difficult to estimate the trade quantity of rice/paddy in the entire country. Because many rice-deficit communes/villages exist in the surplus province, actual trade quantity of paddy/rice should be larger than the simple deficit quantity.

Although some import/export statistics are available from various agents such as FTD/MOC, Custom department/MEF, Port Authority and CAMCONTROL, each figure is based on different sources and has no reliability. There is no statistics for paddy export to neighboring countries because it is an informal export.

Table 2. Rice supply/demand situation in 2003/2004

\begin{tabular}{|c|c|c|c|}
\hline Supply & \multicolumn{3}{|c|}{ Demand } \\
\hline Production (paddy) & $4,710,957 \mathrm{~T}$ & & \\
\hline Production (milled rice) $* 1$ & $2,623,061 \mathrm{~T}$ & Domestic consumption & $1,936,565 \mathrm{~T}$ \\
\hline Reduction for non-food use and & & & \\
\hline Post harvest loss (milled rice)*2 & $800,862 \mathrm{~T}$ & Rice export & NA \\
\hline Rice import & NA & Informal paddy export & NA \\
\hline Information rice import from Thai & NA & (milled rice base) & \\
\hline Open stock & NA & End stock & NA \\
\hline Total (Milled rice) & & Total (Milled rice) & \\
\hline
\end{tabular}

Table 3. Major trade flows

\begin{tabular}{lll}
\hline \multicolumn{1}{c}{ From } & \multicolumn{1}{c}{ To } & \multicolumn{1}{c}{ Kinds/Major variety } \\
\hline $\begin{array}{l}\text { Northwest main production area } \\
\text { (Battambang, Banteay Mean Chey) }\end{array}$ & Phnom Penh & $\begin{array}{l}\text { Rice: Somaly, Phaka Kaguey, } \\
\text { Neang Menh }\end{array}$ \\
\cline { 2 - 3 } & Thailand & Paddy: Somaly, Domely \\
\hline $\begin{array}{l}\text { Southeast main production area } \\
\text { (Takeo, Prey Veng) }\end{array}$ & Phnom Penh & $\begin{array}{l}\text { Rice: IR, Phaka Kaguey, Srov } \\
\text { Krahome, Mixed-rice }\end{array}$ \\
\cline { 2 - 3 } & Vietnam & Paddy: IR \\
\hline
\end{tabular}


Based on data obtained, the rice supply/demand situation in 2003/2004 is roughly assumed as follows:

Rice/paddy trade flows vary depending on crop condition in different Provinces and on the prices in neighboring countries. Trade flows are generated not only by quantity imbalance but also by needs for specific rice variety and quality. Major trade flows are as follows:

In addition, there are minor flows, such as flows southeast production areas to coastal areas and mountainous areas, and a flow of Thai broken rice through the northwest border and then to Phnom Penh. Phnom Penh is the largest rice-consuming center in the country. Various kinds of quality and price of rice flow into the City. As Phnom Penh is located at a hub of the national road network, wholesalers play a role in relaying the rice from the northwest production areas and imported Thai broken rice to provincial towns in the southeast and coastal areas. Except the flows to Thailand and Vietnam, paddy flows in the country are limited. Most paddy is milled in the province of origin or in a neighboring province.

Somaly, Phaka Kagney and Neang Minh, produced at the northwest production areas, have an established reputation for high quality (good taste) and are marketed widely to many urban areas, Phnom Penh, Sihanouk Ville and provincial towns of Takeo, Kandal, Siem Reap, Kampong Cham. Other local varieties are marketed only within the province and/or to neighboring provinces.

Only specific varieties, such as Somaly, Phaka Kagney, Neang Minh, Srov Krahome, Srov Sor, IR and etc. are marketed variety-wise. Several thousands of other wet season varieties are marketed as mixture of varieties (called as 'Mixed-rice' in markets) from the collection stage due to the small quantities produced.

\section{TRANSPORTATION}

Most paddy and rice is transported by road and physical distribution of rice/paddy is efficient as far as transport conditions permit. Regular use of water transport is limited to some areas in the southern provinces, such as paddy transport to the rice mills in Neak Loeung in Prey Veng province, paddy transport to Vietnam through the main/branch streams of the Bassac River and rice transport to Kratie province from Kampong Cham province. The railway was a major mode of rice transportation from the northwest province to Phnom Penh during the 1960's. Now it is estimated that about $80 \%$ of rice is transported by heavy trucks though NR5 (National Road 5). NR5 became impassable and heavy trucks were stacked up in mud during October 2000 due to high level of flooded water, and most truck transport was shifted to railway transport to Phnom Penh.

For road transportation, various means are used depending on distance and road condition. Paddy transport in rural areas is most often by ox-cart for short distances and for the roughest roads within villages/communes (e.g. field to farmer's house, farmer's house to rice mill/middleman's house). In Battambang province, the use of tractors and locally made trucks for paddy transportation is significant. For medium distance within districts (village to local town/rice mill), tractors and truck are used. For long distances (inter-district/inter-provincial transport mostly for rice), heavy trucks over 10 tons are used and 40 tons' heavy trucks with trailers are widely used for rice transport from 
Battambang to Phnom Penh. Transport of rice in town areas by traders is most often by truck and motorcycle. Most of paddy/rice traders including rice millers do not have their own transport. Both large and small-scale traders hire transportation.

200-300 tons' boat transportation is available on demand between Siem Reap and Phnom Penh except during the dry season, but it is not much used to transport rice and paddy at present.

Transport rates for the major destinations are consistent and well known to the users. Rates for short distance truck transport from surrounding areas to town market/rice mill is commonly around 10,000 Riel/ton. Rates for medium and long distances transport vary depending on cases. High rates of over $300 \mathrm{Riel} /$ ton $-\mathrm{km}$ are applied to poor condition roads. In contrast, the cheapest rate is $55 \mathrm{Riel} /$ ton $-k m$ on NR4. Rates for major transport routes, Battambang- Phnom Penh-Sihanouk Ville, are relatively cheaper than those of other routes. A transport company expects $30-40 \%$ reduction in transport rate between Battambang and Phnom Penh if the NR5 is rehabilitated.

\section{MARKETING CHANNELS}

Under the market economic policy, rice/paddy marketing is entrusted entirely in the hand of the private sector. Currently, the government has no market intervention or market control systems for domestic marketing. Under this situation, farmers, middlemen,

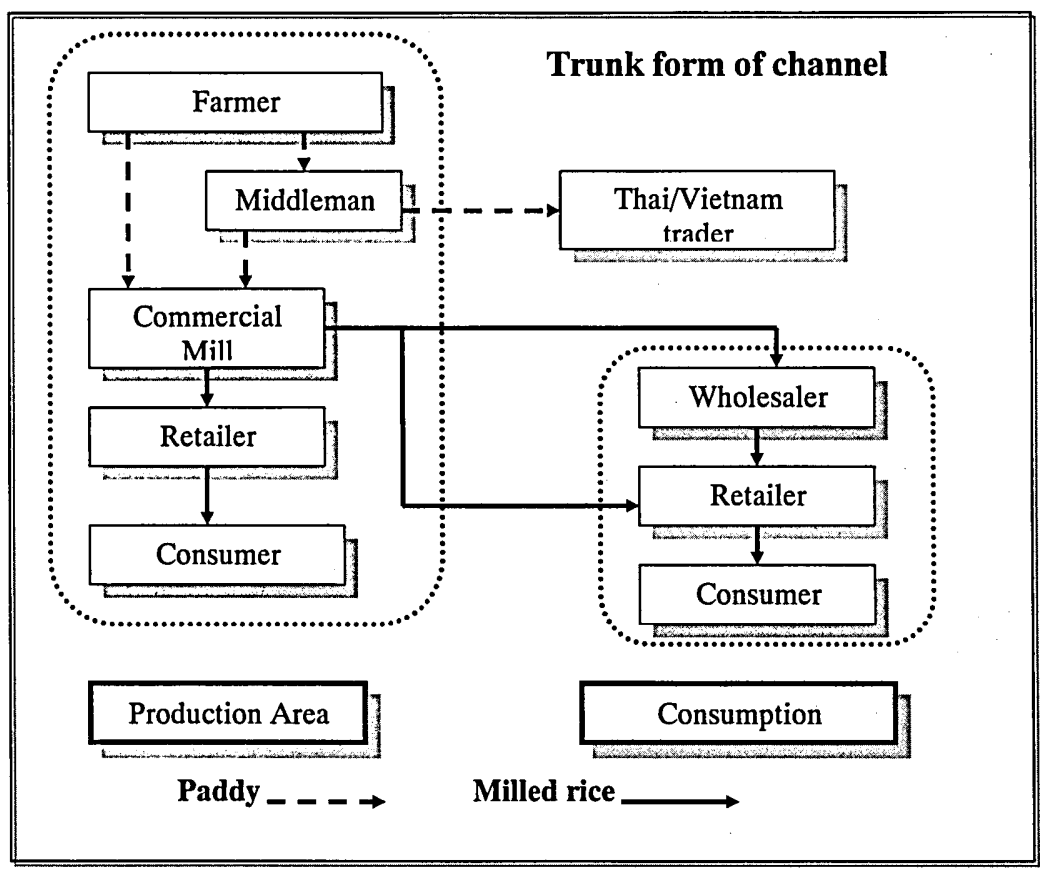

Fig. 1. Marketing channels 
commercial mills, wholesalers and retailers formulate various marketing channels. From the varieties of the channels, a trunk form is abstracted as shown in Fig. 1.

All marketing agents including farmers conduct business by utilizing all available resources. Marketing channels are generally short, as a channel shortcut, such as a farmer's direct sale to rice mills and retailer's direct purchase from rice mills, is widely practiced. Also, channels are flexible to adapt quickly to new opportunities and change direction of trade flow.

Prices prevailing in their immediate area of operation are well known by all agents except farmers.

\section{MARKETING AGENTS}

\section{Farmers}

According to a questionnaire survey, only $40 \%$ of the farmers sold rice, regardless of quantity, during the last 2 years. Average sales volume is 1.6 tons/year and the maximum is about 3 tons/year. Thus, the number of farmers involved in the marketing system is limited. Farmers tend to sell part of the surplus paddy immediately to repay debts and store the rest until they need more money. Except for farmers who have easy access to rice mills/towns, farmers sell surplus paddy to middlemen in the village. Farmers always get cash payments immediately for sales of paddy. At present, no group marketing is carried out in Cambodia.

According to the results of the questionnaire survey, the methods of marketing paddy are shown in the table below. Most farmers (67\%) sold paddy to middlemen. In Kandal province, selling to consumers (in the market or village) is one way of marketing paddy, as well as selling to middlemen. Compared to other provinces, more farmers sell to rice mills in Battambang (45\%) and Kampong Chhang (34\%).

Table 4. Methods of marketing paddy by farmer

\begin{tabular}{lccc}
\hline \multicolumn{1}{c}{ Province } & Sell to middleman & Sell to mill & Other \\
\hline Kandal & $34 \%$ & $13 \%$ & $53 \%$ \\
Prey Veng & $70 \%$ & $16 \%$ & $14 \%$ \\
Kampong Cham & $69 \%$ & $19 \%$ & $12 \%$ \\
Svay Rieng & $59 \%$ & $15 \%$ & $26 \%$ \\
Takeo & $81 \%$ & $4 \%$ & $15 \%$ \\
Kampong Speu & $96 \%$ & $4 \%$ & $0 \%$ \\
Kampong Chhang & $61 \%$ & $34 \%$ & $5 \%$ \\
Battambang & $52 \%$ & $45 \%$ & $3 \%$ \\
Siem Reap & $57 \%$ & $29 \%$ & $14 \%$ \\
Study Area & $67 \%$ & $20 \%$ & $13 \%$ \\
\hline
\end{tabular}

Source: JICA Study Team

\section{Middlemen (Paddy collectors)}

Middlemen play an important role in the marketing of farmer's paddy, especially in remote areas far from rice mills, markets or towns. Large-scale middlemen use agents to 
visit individual farmers and buy paddy. The area for paddy collection is generally fixed within several districts. In areas of rough and poor road conditions, ox-carts are used for transport. Many of rice mills have regular business relations with selected middlemen. Rice millers order specific variety of paddy to middlemen when they receive a large or urgent order. The scale of paddy orders is $20-300$ tons and the rice miller gives $30 \%-50 \%-70 \%$ advance payment.

\section{Commercial rice millers}

Among the marketing agents, commercial rice millers have the largest business scale and play the role of financial suppliers to other agents, making advance payments to middlemen and deferred payments to rice sellers. They also play an important role in paddy storage. Most commercial rice millers keep 300-1000 tons of paddy stock in July-August. In general, $50 \%$ of material paddy is purchased directly from farmers.

Scale of business varies from 200 ton/year to 10,000 ton/year in throughput. Some commercial millers have a combination function as custom mill. Except for a few commercial mills in Battambang, which are formed as a company or partnership, almost all commercial mills are firmly run and categorized as sole Proprietorship.

\section{DOMESTIC TRADE FLOWS}

\section{Trade flows to provincial towns}

Marketing channels to provincial/district towns from surrounding production areas are simple and have not much variation. Rice sellers in each town buy the locally produced rice directly from rice mills nearby. In addition to the local rice, sellers procure several kinds of rice according to the needs of local consumers from rice mills/wholesalers in other provinces. Paddy does not flow through the markets in provincial towns.

Notable characteristics in rice supply to provincial towns are summarized as follows:

- No rice flow into the provincial towns of Battambang and Banteay Mean Chey from

Table 5. Retail shops and rice prices in and out of Phnom Penh

\begin{tabular}{lccccc}
\hline \multirow{2}{*}{ Variety/kinds } & \multicolumn{2}{c}{ In Phnom Penh/1 } & & \multicolumn{2}{c}{ Out of Phnom Penh } \\
\cline { 2 - 3 } \cline { 5 - 6 } Somaly & Price(Riel/kg) & Shops selling & & Price(Riel/kg) & Shops selling \\
\hline Pha kagney & $1100-1560 *$ & $21 \%$ & & 1500 & $3 \%$ \\
Neang khon & $900-1100$ & $17 \%$ & & $900-1200$ & $22.5 \%$ \\
Neang Menh & $850-1000$ & $13 \%$ & & NA & $0 \%$ \\
Srov Sar & $750-900$ & $17 \%$ & & $800-1000$ & $17 \%$ \\
Srov krahome & $800-850$ & $3 \%$ & & $750-900$ & $14 \%$ \\
IR\& State rice & $750-900$ & $3 \%$ & & $700-900$ & $7 \%$ \\
Other local varieties & $590-800$ & $9 \%$ & & $500-800$ & $17 \%$ \\
Thai rice* & $780-1014$ & $1 \%$ & & $600-1000$ & $7 \%$ \\
\cline { 1 - 2 } & $858-3500^{*}$ & $16 \%$ & & $1000-1300^{*}$ & $12.5 \%$ \\
\hline
\end{tabular}

/1 Rice shops near Railway Station and near Orussey market (sample 23 shops)

/2 Rice shops in Takmao market, Kandal province (sample 15 shops)

Prices vary depending on the production area. *Include several different grades 
other provinces. Moreover, even though closest to Thailand, no Thai broken rice is marketed because both provinces are surrounded by production areas with high value varieties.

- Although Takeo province has the largest surplus in the country, rice from Battambang (rice of good taste) flows into the provincial town to meet consumer needs.

- Only high-price rice (Battambang rice and Thai rice) flows into Siem Reap because it has large tourist demands.

- Only the cheapest rice (IR rice) flows into Kratie town.

- The lowest rice price in each town is commonly $600-650 \mathrm{Riel} / \mathrm{kg}$, with either IR or Mixed-rice.

\section{Trade flows to Phnom Penh}

Phnom Penh has a population of about 1.1 million and is the largest market in the country. Rice of various kinds, quality and price is marketed here. All kinds of domestic rice are shipped directly from rice mills in production areas to wholesalers/retailers in Phnom Penh by the national road network.

Pha Kagney, Neang Menh, Neang Khon, Wet Season Mixed-rice, IR rice and Thai broken rice are popular rice varieties in Phnom Penh markets. There is a clear price order among those varieties/kinds of rice.

High/medium priced rice such as Somaly, Pha kagney, Neang Menh from Battambang is the most common in the city center where residents have the highest income level in the country. In contrast, medium-low priced rice from surrounding provinces such as IR, local variety and mixed-rice is common in the outskirts of the city area where lower income earners live.

Rice from the northwest production areas, namely Battambang, has an established reputation of good taste and good quality. It has a large market share in the high-medium price market in Phnom Penh. Now quality competition has started among rice mills in Battambang seeking outlets in Phnom Penh, due to the market's limited size.

IR rice produced in the southern part of the country such as Takeo and Prey Veng is evaluated poor in taste and the cheapest rice in Cambodia. In Phnom Penh, IR rice is marketed mostly for factory lunch consumption and for low-income earners living in the outskirts of the city. IR rice is sold only at a few markets in the city center. Pha kagney produced in Takeo is $100-150 \mathrm{Riel} / \mathrm{kg}$ cheaper than the same produced in Battambang, due to "hard taste."

The "look" of rice is an important factor in determining price (quality) in the market. Therefore, foreign matter and colored grain are all removed before retailing. This practice is not applied to the Battambang rice.

Thai broken rice is sold at most rice shops in the center of Phnom Penh. Consumers value this rice and considered as "It is soft and it maintains softness even when rice gets cool." In contrast, Cambodian rice is considered as "It becomes hard when it is cool." Many local restaurants use Thai broken rice for blending with local rice to add fragrance and softness.

The number of rice sellers in the major markets is counted as around 150-200. As 
the registration system has not covered small-scale businesses, rice sellers outside of the markets are not known.

Wholesalers have business relations with 3 to 10 mills, and with $20-50$ retailers. Their business is to replenish after selling and do not keep large stocks (300 tons of stock as maximum, ordinary is less 100 tons).

Stall shop owners in several markets expressed their concerns that: "It isn't possible to bring up a family with a rice shop. Too many rice shops and too few sales this year." Orussey market has shifted into a new building since the $3^{\text {rd }}$ of August. Before shifting, there were about 90 shops but it decreased to about 30 shops because many sellers changed to selling other goods.

\section{TRADE FLOWS TO THAILAND AND VIETNAM}

The main reason for the paddy flow to Vietnam is lack of a domestic market for irrigated early rice (specially IR variety). The main reason for the paddy flow to Thailand is a physical difficulty and high costs of transporting commodities within the northwest regions and/or higher profits. Due to this informal export, there is no trade data. This is a major hindrance to estimate the national food balance and to formulate policies and intervention measures.

\section{Paddy flows to Thailand}

Paddy flows to Thailand from Banteay Mean Chey province, Battambang province and Siem Reap province through 'smuggling corridors' along the northwest border. Among the three provinces, it is presumed that the flow from Bantheay Mean Chay province is the largest.

In Banteay Mean Chay province, farmer's scale of rice production is large, over 5 ha and farmers grow high value variety such as Somaly and Domaly. But due to unstable social conditions until the recent years, commercial rice mills have not yet been established in this area. At present, there are only 2 commercial rice mills between Sisophone and Poipet, and no commercial rice mills in the north of Sisophone up to Thai border. The road condition is also extremely poor. Reportedly, not only middlemen but also many farmers carry paddy by push cart/animal cart to Thailand.

In contrast to Banteay Mean Chay province, Battambang province has well-established commercial rice mills. Middlemen in Bavel district, a major surplus area in the province, regularly collect price information at the Thai border and rice mills along NR5 and ship the paddy at higher profits.

At districts close to the Thai border, 'district to district level' discussions about border trade are made with local authorities on the Thai side. As a result of this, regular, though very limited, paddy trade is conducted at a border gate in Banteay Mean Chay province.

At present time, there is no public market facility for border trade in Cambodia. Besides this poor situation, modern market facility has already established or under-preparation in Thai side at major border gates in Battambang and Banteay Mean Chay province. 


\section{Paddy flows to Vietnam}

In the border area with Vietnam, the population on the Cambodian side is thin. Though the figure is unknown, considerable areas are leased to Vietnamese farmers for rice cultivation and all paddy produced on the leased land is collected by Vietnamese paddy collectors. Large-scale export factories are located at only $30-40 \mathrm{~km}$ across the border. Thus, this border area has the best access to export facilities in Cambodia.

The majority of paddy flows to Vietnam is considered as IR variety. It was reported that due to low export prices during Feb- June in this year, few Vietnamese paddy collectors came to buy paddy in Takeo province and farmers were left with unsold stocks of paddy.

In Vietnam, paddy/rice is distributed by waterways in a dense network of irrigation/waterway canals. Thus the major mode of paddy transport to Vietnam is by waterways and Vietnamese traders come up the main/sub streams of the Bassac River and Mekong River. Several local ports in Takeo province are used as loading places. NR2 and several byways though rice filds are also used to reach the border. In Kandal province, paddy is loaded along banks of Bassac River.

At Angkor Borei port in Takeo, a Cambodia paddy trader is stationed to purchase paddy and he waits for prices to rise in Vietnam. Trader carries paddy by boat to a place near the Bak Day border gate where he meets Vietnamese traders without preliminary contact. Vietnam's paddy prices are obtained from boats coming to Angkor Borei from Vietnam. Paddy trade at Angkor Borei begins in April and continues to November, with the peak times in June/July.

Several large-scale paddy traders are located at Neak Loeng in Prey Veng province. A trader estimates his annual trade at 10,000 tons of paddy, of which $60 \%$ is sold to Vietnam. This trader sells paddy to Vietnam traders though several Cambodian boarder traders. Vietnamese buyers come up to Neak Leung in 30-50 ton boats together with a Cambodian boarder trade. The fee to pass though the boarder is estimated at 50-70 VND $/ \mathrm{kg}$ including commission to the Cambodian boarder trader.

Other Cambodian border traders who deal with bean, maize and tobacco are stationed at Neak Leung. They have regular contracts with several Vietnamese traders and buy commodities after receiving orders from them.

Along the Vietnam border in Takeo and Prey Veng province, there are local markets at the opposite side of border (at the opposite side of the channel) but facilities are in a poor condition. It should be noted that most of Vietnam border areas inundated for about three months every year.

\section{Policy on paddy trade}

General agreements on trade cooperation between respective countries were made and promotion of bilateral trade and border trade is clearly stated in the agreements. But it seems that no definite (written) agreements about paddy border trade exists. The actual situation of paddy trade at border is described as follow:

\section{Thailand}

Reportedly paddy trade is banned. Legislation stipulating the ban of paddy imports has not yet been confirmed. Thailand local authority has some flexibility in border trade 
and admits the paddy import with a limitation of amounts at a certain gate.

\section{Vietnam}

Vietnam government allows Vietnamese people residing permanently in border areas to trade goods at border. Also it allows Cambodian people with legal permanent residence in border areas in Cambodian territory to conduct trade at border markets in Vietnam if they have border passes issued by the relevant Cambodian authority. The commodities worth less than VND 500,000 carried across the border to Vietnam will be exempted from tax once in a day (Decision 24/1999/QD-BTM, June 1999).

Rice imports need the permit from the Ministry of Trade (Document No.2860, June 1999). According to the hearing from Vietnam traders, paddy import is legalized with import tax, but rice import is banned in border trade.

\section{Cambodia}

Paddy export is not banned in Cambodia but it is required to get an export license. Practically it is impossible to get a license for small-scale paddy trader and farmers who live at the border areas in their daily life, and they have to ship paddy to market of neighboring countries with an informal way. Moreover, it gives a chance for government officials to collect illegal fees.

\section{Fee collection at border areas}

Thailand border

According to the hearing at a gate where paddy trade is admitted by both Thai and Cambodia local authorities with a limitation of amount, Cambodia authorities collect Bath 10-8/bag (100-120 kg), i.e. 10,000-6,700 Riel/ton. No data was obtained about formal/informal fees in Thai side.

\section{Vietnam border}

According to the hearing from Vietnamese traders, total of informal fees in Cambodia side is calculated as $6,570-9,500 \mathrm{Riel} /$ ton and fee and tax in Vietnam side is about $31,000 \mathrm{VND} / \mathrm{kg}(8,430 \mathrm{Riel} / \mathrm{ton})$ including $34,000 \mathrm{VND} /$ ton of tax collection on about $50 \%$ of cargo values.

The profit of Vietnam trader is roughly estimated as $120 \mathrm{VND} / \mathrm{kg}$. This is the usual level of profit for paddy collection in Mekong Delta in Vietnam.

\section{RICE EXPORT}

There is no restriction on rice export but exporters need to apply an export license from the government. Under the free trade system, private traders export small amounts of rice. Singapore is a major destination and it occupied $82 \%$ of total exports and high quality rice was a major export.

Export costs for dry cargo container (20 feet) are quoted at USD 20.9/ton by a forwarder. Informal fee payments for port procedures are included in the quotation and it makes custom/port clearance fees very costly. 
Table 6. Export costs from Phnom Penh to Sihanouk Ville

\begin{tabular}{lcc}
\hline \multicolumn{1}{c}{ Item } & Cost per 20 ft. container & Cost per ton \\
\hline Inland truck fee (Phnom Penh to S. Ville) & 170 & 7.7 \\
Custom clearance and Port clearance & 230 & 10.5 \\
Loading fee on to vessel & 25 & 1.1 \\
Customs, Camcontrol, Police inspection & 35 & 1.6 \\
Total & 460 & 20.9 \\
\hline
\end{tabular}

Note: 22 tons rice/20 ft. container, Exchange rate: Riel 3,850/USD

\section{PRICE MECHANISM}

\section{Price trend}

Retail prices in Cambodia showed similar fluctuations with the US\$ exchange rate until September/October, 1999. After a sharp drop at the end of 1998, although it once recovered, rice prices remain at low levels in US $\$$ values during January- August. Rice prices decrease during the main harvest season (November - January) and increase during the off-season (flood season).

Paddy prices and rice prices of Cambodia, Thailand and Vietnam show similar fluctuations. According to correlations among these prices of three countries, Thailand prices and Vietnam prices have a high correlation, and Vietnam paddy price has a significantly high correlation with IR rice price in Takeo. The correlation between Thailand and Cambodia prices is less than that of between Vietnam prices and Cambodia prices, especially in recent years (see Table 7 and Table 8).

Although the farmers hoped to sell their paddy about 350 to $380 \mathrm{Riel} / \mathrm{kg}$, paddy price stayed lower than that during the JICA study period (see Table 9).

Table 7. Paddy rice producer price (in local currency)

\begin{tabular}{lrrrrrrrrrrrr}
\hline & 1991 & 1992 & 1993 & 1994 & 1995 & 1996 & 1997 & 1998 & 1999 & 2000 & 2001 & 2002 \\
\hline Cambodia & 101,401 & 110,000 & 350,000 & 380,000 & 520,000 & 470,000 & 510,000 & 590,000 & 420,000 & 370,000 & 412,000 & 470,000 \\
Thailand & 4,089 & 3,822 & 3,215 & 3,854 & 4,132 & 5,372 & 5,472 & 6,629 & 5,579 & 4,808 & 4,484 & 4,425 \\
Vietnam* & 293 & 268 & 237 & 270 & 322 & 339 & 304 & 305 & 248 & 202 & 173 & 192 \\
\hline
\end{tabular}

Source: FAO, FAOSTAT

* means the data is obtainrd from USDA, Rice Situation Outlook, $5 \%$ broken export price ( $\$ /$ ton).

\section{Price difference among provinces}

In Cambodia, rice varieties produced in each province are varied, and most local varieties are marketed only within the province and/or to neighboring provinces. Only the varieties of Somaly, Pha kagney, Neang Minh produced in the northwest production areas are marketed to many provincial towns. Due to no accumulated price data in which 
Table 8. Rice correlation coefficients

Price Correlation Coefficients during 1991-2002

\begin{tabular}{lrcc}
\hline & Cambodia & Thailand & Vietnam \\
\hline Cambodia & 1 & & \\
Thailand & 0.598565 & 1 & 1 \\
Vietnam & 0.126031 & 0.287249 & \\
\hline \multicolumn{5}{c}{ Price Correlation Coefficients during $1992-2002$} \\
\hline \multicolumn{5}{c}{ Cambodia } & Thailand & Vietnam \\
\hline Cambodia & 1 & 1 & 1 \\
Thailand & 0.621543 & 0.331945 & \\
Vietnam & 0.300837 & 1 & \\
\hline \multicolumn{5}{c}{ Price Correlation Coefficients during $1993-2002$} \\
\hline \multicolumn{5}{c}{ Cambodia } & Thailand & Vietnam \\
\hline Cambodia & 1 & 1 & 1 \\
Thailand & 0.68476 & 0.363131 & \\
Vietnam & 0.588119 &
\end{tabular}

Price Correlation Coefficients during 1994-2002

\begin{tabular}{lrrr}
\hline & Cambodia & Thailand & Vietnam \\
\hline Cambodia & 1 & & \\
Thailand & 0.582084 & 1 & \\
Vietnam & 0.596249 & 0.349094 & 1 \\
\hline
\end{tabular}

Price Correlation Coefficients during 1995-2002

\begin{tabular}{lrrr} 
& Cambodia & Thailand & Vietnam \\
\hline Cambodia & 1 & & \\
Thailand & 0.478329 & 1 & \\
Vietnam & 0.679281 & 0.426019 & 1 \\
\hline
\end{tabular}

Price Correlation Coefficients during 1996-2002

\begin{tabular}{lrrr}
\hline & Cambodia & Thailand & Vietnam \\
\hline Cambodia & 1 & & \\
Thailand & 0.738612 & 1 & \\
Vietnam & 0.643605 & 0.75518 & 1 \\
\hline
\end{tabular}

Price Correlation Coefficients during 1997-2002

\begin{tabular}{lrrr}
\hline & Cambodia & Thailand & Vietnam \\
\hline Cambodia & 1 & & \\
Thailand & 0.738129 & 1 & \\
Vietnam & 0.766675 & 0.886621 & 1 \\
\hline
\end{tabular}

Price Correlation Coefficients during 1998-2002

\begin{tabular}{lrrr} 
& Cambodia & Thailand & Vietnam \\
\hline Cambodia & 1 & & \\
Thailand & 0.736736 & 1 & \\
Vietnam & 0.76033 & 0.988398 & 1 \\
\hline
\end{tabular}


Table 9. Farmer's selling prices

\begin{tabular}{|c|c|c|c|}
\hline Year \& Month & Province & Variety (Crop season & $\begin{array}{l}\text { Price of paddy } \\
\quad \text { (Riel } / \mathrm{kg} \text { ) }\end{array}$ \\
\hline April to May , 2003 & Prey Veng & IR (dry) & 350 to 360 \\
\hline Sep. to Oct, 2003 & Prey Veng, Kandal & Mixed rice (wet), IR (dry) & 420 to 410 \\
\hline Nov. to Dec,2003 & Prey Veng, Kandal & $\begin{array}{l}\text { Mixed rice, Banla Phdau, } \\
\text { Other local varieties (wet) }\end{array}$ & 440 \\
\hline Feb, 2004 & Takeo, Battambang & $\begin{array}{l}\text { Mixed rice, other local varieties } \\
\text { (wet) }\end{array}$ & 300 to 410 \\
\hline Mach, 2004 & Whole Cambodia & $\begin{array}{l}\text { IR (dry), Mixed rice, other local } \\
\text { varieties (wet) }\end{array}$ & 350 to 430 \\
\hline
\end{tabular}

Source: JICA study team

variety and origin identical is available, clarity the price differences between provinces.

Price differences between provinces of Somaly, Pha kagney and Neang Minh produced at Battambang are small. Price of IR variety rice, which is always cheapest in the markets, is in the same level among several provinces. It is noteworthy that prices of mixed rice, which are mixture of minor wet season varieties and have different content of varieties depending on the province, also are in the same level (Riel 600-700/kg) among all provincial towns in Cambodia.

\section{Price difference among varieties/grades}

There is a definite price order among major marketed varieties that is Somaly, Phakagney, Neang Minh, Neang khon, Mixed rice, IR, and this order never change in the markets.

In Phnom Penh, some wholesalers and retailers have different grades of rice, called as No 1 and No 2, in higher price varieties such as Somaly and Phakagney. The price difference between grades is normally $100-200 \mathrm{Riel} / \mathrm{kg}$. Rice sellers explain the difference is in appearance (clearness) which comes from different degrees of milling, broken rice

Table 10. Retail prices by variety

(Unit: $\mathrm{Riel} / \mathrm{kg}$ )

\begin{tabular}{lccc}
\hline Variety/Grade & $\begin{array}{c}\text { Phnom Penh } \\
\text { (origin) }\end{array}$ & Siem Reap Town & Battambang Town \\
\hline Somaly & $1300-1400$ (BTB) & $900-1000$ & $1200-1300$ \\
Phakgney & $900-1100$ (BTB) & $1000-1100$ & $900-1100$ \\
Kraya & NA & 1200 & 700 \\
Neang Khon & $900-1000$ (BTB) & $800-850$ & 700 \\
Neang Minh & $800-900(\mathrm{BTB})$ & $750-800$ & $600-680$ \\
Local (mixed) & $700-800$ (PP,KS) & $600-700$ & NA \\
IR & $600-650(\mathrm{TK})$ & NA & NA \\
Thai broken rice & $1000-1200$ (BTB) & NA & \\
\hline
\end{tabular}

Source: JICA study team 
rations, or production areas (taste). Although it appears that some common scale/sense of quality evaluation exists among the traders, no numerical indicator is used for grading the rice quality in domestic trade.

\section{Price relations with Thailand/Vietnam rice}

Cambodia rice/paddy prices receive the influences of international market prices through Vietnam at the southeast and through Thailand at the northeast. Since prices in both Thailand and Vietnam have a very similar fluctuation each other, paddy/rice prices in both the southeast and northeast production areas also show a similar fluctuation each other, as mentioned earlier. At the variety level, paddy prices in Vietnam (i.e. export grades) have significant influences on the price of the cheapest rice (IR variety) in Takeo and Prey Veng. With a definite price order among the varieties in domestic markets, fluctuations in IR variety shift the price of the next cheapest rice (Mixed rice) in the provinces. The highest priced rice (Somaly) is mainly produced at the northwest production areas, and it is reported that Thai traders buy Somaly/Domaly with higher prices than other varieties. Thus, the price in Thailand has influences on the price of highest priced rice. Rice prices tend to show a seasonal fluctuation pattern: decreasing during the main harvest season (November- January) and increasing during the off-season (flood season), although the rang and pattern of fluctuations are influenced by the international market price.

Table 11. Export amounts and turnover

\begin{tabular}{lccc}
\hline Year & Q'ty (M/T) & Turnover (USD) & Average FOB (USD/ton) \\
\hline 1996 & 16,310 & $4,314,070$ & 265 \\
1997 & 10,947 & $3,234,815$ & 295 \\
1998 & 3,080 & 808,840 & 263 \\
1999 & 7,390 & $1,632,310$ & 221 \\
2000 (Jan-Apr.) & 600 & 154,000 & 257 \\
\hline
\end{tabular}

Source: Foreign Trade Department/MOC

Notes: Although several export-import data is available from Custom department/MEF, FTD/MOC and Camcontrol, each data shows different figures because data source are different from each other.

\section{MARKET INFORMATION SYSTEM OF RICE}

\section{MAFF}

The current Market Information System (MIS) for agricultural commodities was set up through the FAO project providing technical assistance, training, equipments and a budget for general operating expenses. It started full-scale operations in August 1997. This MIS collects the rice/paddy prices of fixed varieties at 11 places in the country.

Collected price data is transmitted daily to the Agricultural Marketing Office of DPSC from the provinces by fax or telephone. The following rice/paddy prices are disseminated though a daily radio program of National Radio Cambodia. Due to time limitation of the program, only selected information is broadcasted.

In addition to this quick dissemination of price information, yearly bulletins are issued 
Table 12. Rice/Paddy Prices disseminated though a Daily Radio Program

\begin{tabular}{|c|c|c|c|}
\hline & Province/Variety & Type of Price & \\
\hline Paddy & $\begin{array}{l}\text { Kandal/Phakagney } \\
\text { Takeo/IR }\end{array}$ & $\begin{array}{l}\text { Rice mill in Takmav } \\
\text { Rice mill }\end{array}$ & $\begin{array}{l}\text { Buying } \\
\text { Buying }\end{array}$ \\
\hline \multirow[t]{3}{*}{ Rice } & $\begin{array}{r}\text { Phnom Penh / Phakagney (BTB) } \\
\text { Neang Minh (BTB) }\end{array}$ & Near Railway station & Buying\& selling \\
\hline & Kandal/Phakagney & Rice mill in Takmav & Selling \\
\hline & Takeo/IR & Rice mill & Selling \\
\hline
\end{tabular}

and provided to DOA and other relevant institutions as well as IOs and NGOs.

Current Problems:

- Disconnected telephone: Sometimes due to delay in budget release and bill payments, the telephones are disconnected.

- Accuracy of collected information: difficulty in collecting the true market price from traders.

- Lack of appropriate trainers for staff training.

- Shortage of budgets for monitoring MIS activity in the provinces.

- Difficulties in negotiating with a private radio station.

\section{MOC}

The MOC has been collecting for wholesale prices of rice No 1 and rice No 2 together with 51 other commodities in 14 provinces. The information collected has never been disseminated with any urgency to the public. It is published as part of a weekly business roundup and provided to relevant institutions. The collected rice price data is hard to analyze because the variety for rice No 1 and rice No 2 is not the same among the provinces.

\section{EDC (Enterprise Development Cambodia)}

EDC has been assisting the rice millers through the formation of the Rice Miller's Association (RMA) at provinces and Federation of RMA, exposure and awareness study tours to Thailand, Singapore and Vietnam to help build social capital for economic developments. EDC has been providing international market information to RAMs periodically. EDC is setting up a communication and information network among RMAs, called RICENET, through the internet and is currently designing its homepage.

\section{Phnom Penh municipality (Management office at the markets)}

Market management offices at most of markets in Phnom Penh City collect the price information on commodities daily. The collected data is usually sent to the district governor office. It has never been disseminated to the public.

\section{DEVELOPMENT CONSTRAINTS}

There are constraints relative to the aspect of rice marketing, many of which are com- 
mon across the regions, provinces, and to the marketing of other agricultural products.

\section{Limited capacity of domestic absorption of incremental production}

Cambodia has been in rice surplus situation over the past 5 years. Considering the present high level of cereal consumption, there is not much scope of greater domestic absorption of increment production. At present, absorption of the rice surplus is highly dependent on neighboring countries, although its export is carried out informally.

\section{Poor marketing infrastructure}

In Cambodia the basic infrastructure required for improved economic activity is underdevelopment. The very poor condition of roads, such as NR5, NR6 and farm to market roads, is a serious obstacle to more efficient trade. Even with rehabilitation efforts, about half the length of national roads needs major improvements. Most provincial and tertiary roads are broken and damaged, with many being impassible during the rainy season. In urban areas, the run-down condition of most markets in terms of cleanliness, drainage and truck access is another major obstacle to efficient trading activities.

Lack of nationwide telecommunication system also hinders efficient trade activity. Although several mobile-phone networks have been developed, communication is still limited to urban areas and costly. Larger traders such as rice millers and wholesalers are equipped with ICOME for local communication. But small-scale traders and farmers, even government offices in remote areas, lack effective means of communicating with urban areas.

\section{Poor financial service system}

Even the basic banking services required for most business operations are currently unavailable in the provinces. Settlement of accounts between rice millers in the provinces and rice sellers in Phnom Penh are mostly done face to face. In some cases, informal remittance services of gold shops are used to settle accounts between provinces.

Banks do no offer long term lending, and the maximum lending period is only 1 year. Although many NGOs provide minimum financial services in the country side, no loan conditions meet the requirement of rice millers for their facilities or for procuring paddy.

\section{Illegal fee collection}

With police and army heading the list, government officials collect illegal fees from the private sector. These illegal fees increase marketing costs in addition to difficulties in transportation due to poor road conditions. Illegal fees are routinely collected at the following places/phases of rice marketing:

- Road fee collections at provincial towns, Phnom Penh city, Sihanouk Ville port etc.

- Fee collections at border areas.

- Custom clearance and other exporting procedures.

\section{Informal paddy export}

Physical difficulties and high costs of transporting commodities within Cambodia and more accessible and better mills on the other side of the border, make markets in the border provinces integrating with those of the neighboring countries. Often it is more 
profitable to sell surplus paddy across the borders than to the domestic markets.

The main reason for the paddy flow to Vietnam is lack of a domestic market for irrigated early rice (specially IR variety). The main reasons for the paddy flow. to Thailand are physical difficulties and high costs of transporting commodities within the northwest region and/or high profits. Due to this informal export, there is no trade data. This is a major hindrance to estimate the national food balance and to formulate policies and intervention measures.

\section{Informal Thai rice import}

Thai fragrant broken rice is informally imported to Cambodia via the small corridors along the Thai border and via the formal gates without leaving a record, then it is marketed to Phnom Penh and the other provincial towns to fulfill the need for high quality rice of urban residents. As with the above informal export of paddy, lack of trader data is a hindrance to estimate the national food balance.

\section{Restricted opportunities for farmers to see better buyers}

Farmers often have limited outlets for their paddy and often bound to sell to middlemen because of poor conditions of farm to markets roads, and many include an element of credit provision by the middleman. Opportunities for farmers to see better buyers are restricted. Such opportunities are further hindered by small quantities produced by most farmers.

Farmers rend to bring the paddy to close by rice mills by themselves, but in remote areas they rely on the limited number of collectors, as there are not many options. Farmers who have no commitment inquire prices from as many collectors as possible but find not much difference. Some farmers explain the reasons to sell their paddy soon after harvest as: 1) shortage of storages, 2) needs for cash, 3) storage losses due to rats and other reasons, 4) not much gain even in the lean season.

Table 13. Rice Production Cost by Employment of High Quality Seed

\begin{tabular}{lcc}
\hline Description & Average Cambodian Farmer & AQIP Quality Rice Seed \\
\hline Average amount of seed required & 70 & 40 \\
(kg/ha) & 400 & 1,500 \\
Approx. cost of rice seed (Riel) (1) & 28,000 & 60,000 \\
Cost (Riel) & & 32,000 \\
Investment required & $100 \%$ & $120 \%$ \\
AQIP estimates of increase yields (2) & 2.0 & 2.4 \\
Yield increase assuming 2 MT/ha & & 400 \\
Yield grain in kg & & 160,000 \\
Additional yield (Riel) & & 128,000 \\
Total profit (Riel) & & $(32$ US\$) \\
\hline
\end{tabular}

Note: Increased yield vary from 15 to $40 \%$ depending on varieties and planting technique. Source: A Rice Seed Profit Story by Super Seed Company-AQIP.

\section{Weak bargaining power of farmers}

Despite the definite price order existing among rice/paddy varieties, the price dif- 
ference of high and low quality varieties in rice mill buying prices, especially in Battambang, is relatively small compared to the price difference in urban markets. Price is always decided by negotiation, but the information resource available to farmers is limited. In most cases, farmers get price information from neighbors or buyers. Also, no numerical indicator is applied in paddy quality evaluation except a few rice millers in Battambang, and the farmer's capability to evaluate paddy quality is limited.

In some communes, there exist a collector who dominates the marketing by lending money, selling seeds and fertilizer on credit to the majority of farmers. They are conditioned to sell their paddy to the collector if they bought seeds or fertilizer on credit (cash credit does not bind the borrowers in the market). The prices, terms and conditions are all determined by the collector and most of the farmers who rely on him have almost no other options once they borrowed money.

Most paddies are not usually stocked much longer until the price goes up. Farmers usually sell their paddy right after the harvest in order to pay for the debt or some necessary expense such as for ceremonies, children's wedding, sick, and clothing, etc in anyhow, while farmers would still complain. It is because not only paddies are sold with cheap prices, but also they lose from weighing as well. Farmers would still end up selling their paddy, anyway.

\section{Weak marketing capability of rice millers}

Northwest production areas such as Battambang and Banteay Mean Chey have an established reputation for high quality (good taste) rice. It dominates the domestic high quality rice markets in Phnom Penh city and some provincial towns. There are several other local varieties of high quality (good taste) in some other provinces around Phnom Penh. But the weak marketing capability of rice millers in these provinces hinders their expansion and outlets in Phnom Penh markets. This in turn limits the market for farmers.

\section{Weak incentive for physical quality improvements}

Based on income levels and buying power of consumers, the markets in urban and provincial towns have different needs. At lower buying areas such as Kampong Speu town, consumer needs are for cheapness. Therefore the physical quality is kept interior levels (high contents of small broken rice) deliberately to maintain a lower price for the consumers. On the other hands, in Phnom Penh, where consumers have the highest income levels in the country, consumer's first criteria for choosing rice is its variety and few complaints are raised about physical quality.

\section{Constraints in Market Information Service}

\section{Difficulty in disseminating provincial information}

Due to time limits of the MIS radio program, it is unable to disseminate all provincial information, and there exists a mismatch between what the farmers/traders want to know and the program content. Negotiations for "free" broadcast with a private radio station in the province were attempted but so far none of them have been successful.

\section{Duplication of data-gathering activity}

Beside the AMO/MAFF, several governmental institutes, including MOC, also collect 
the marketing information of agricultural commodities. But there is no cooperation in data collection/exchange at present time.

\section{Scarce records for import and export}

There are several export/import records available from the Custom Department/MEF, Foreign Trade Department/MOC, Camcontrol and Port Authority. All these records are based on different sources of information and have no consistency with each other. In addition to their unreliability, the lack of border trade data is the biggest hindrance to estimate the national food balance and to formulate policies and intervention measures.

\section{Weak Institutional Capacity}

The institutional capacity for supporting the private sector is weak. Beside the constraints in MIS activity mentioned above, the lack of capable and experienced staffs remain the biggest constraint of AMO/MAFF in providing marketing supports to farmers and traders. Worse situation is encountered in MOC.

\section{Unfair dealing in State rice procurement}

Reportedly there are unfair dealings in the government's rice procurement for the army and police supply, and collusion in the WFP rice tender. These large quantities of rice procurement may influence the market price. The government should have a mechanism such as Fair Trade Commission to supervise such large transactions to maintain fairness and transparency.

\section{Rice Import by WFP}

Although it may be cheaper to import rice from neighboring countries when the need arises, it would be desirable for donors, include WFP, to purchase local rice surplus for internal transfers to deficit areas. Apart from cost savings, this would help supporting prices in surplus areas in Cambodia.

\section{CONCLUDING REMARKS: WHAT SHOULD BE IMPROVED?}

With the yield growth and planted area expansion, the country achieved overall rice "surplus" in 1995 and this has been sustained until now. It must be noted that attaining self-sufficiency despite weak infrastructure, low adaptation of modern technology, and a rapidly increasing population indicate considerable potentials for further rice production. Needless to say, availability of food supply is a necessary condition for food security and a situation of steady supply is clearly preferred to stabilize food prices: and improve real incomes of the poor. At present, absorption of the surplus rice is highly dependent on the informal paddy trade with neighboring countries.

Despite Cambodia being in a favorable situation of rice surplus, the agricultural production system in Cambodia still remains highly vulnerable to weather shocks and pest damage. Stabilization and expansion of rice production remains an immediate problem to be solved. From the marketing aspect, it is essential to give incentives for farmers to increase production. One such is to improve farmer's income by strengthening their bargaining power and expanding markets. 
Despite the large amounts of paddy flowing out to the neighboring countries, there is no trade record due to informal exports. To improve the paddy trade, it should be liberalized and legalized. By doing so, traders will pass through formal boarder gates, which will eliminate illegal fee collection at border areas, and it will also enable official recording of trade. Moreover, the bargaining power of Cambodia traders should be improved and the paddy trade should be converted to a milled rice trade.

Domestic markets have different needs according to the buying power of residents in each area. Each production area shall attempt marketing to match the regional needs. In Phnom Penh, large amounts of imported Thai fragrant broken rice are sold for blending with domestic rice to add fragrance. This imported Thai broken rice should be replaced with domestic rice by enhancing the production of fragrant variety.

Despite an overall "surplus" situation, many Cambodians lack access to food supply due to insufficient purchasing power, poor roads and due to more profitable markets to sell. These poor roads need to be rehabilitated to reduce the marketing cost and the distribution barrier to deficit areas, and to meet the potential demands. Another factor increasing marketing costs is the illegal fee collection by police, army and civil workers: this must be eliminated immediately.

Consumers who do not care about some degrees of broken rice are satisfied with the present quality of rice. Rice processed in Battambang province has an established brand value and dominates the domestic high quality rice markets in Phnom Penh and in some provincial towns. If the industry develops with foreign capital investments, it is expected that the demand for high quality rice will increase as the income of city dweller improves. Other production areas should consider introducing a fragrant/soft type of rice to fit the consumer's taste. Another constraint to competing with Battambang rice in Phnom Penh markets is the weak marketing capability of rice millers. Rice millers should take an initiative to formulate a vertical integration of rice production-processing-marketing with farmers for mutual benefits. Competition in high quality markets among the provinces shall lead the overall quality improvement in the country, and then lead to further possibilities of entering the overseas markets.

Another problem in the marketing system is weak bargaining power of farmer's. To give incentives for farmers to increase production, creation of a paddy market, where many buyers and sellers gather for their paddy transaction, shall provide more opportunities for farmers to see better buyers. Also, such markets shall form the openindex-price reflecting the supply/demand situation of the production area. By sending other production areas clear price signals regarding quantities and varieties required, it will also facilitate spatial distribution to fill the price gaps among provinces and reduce price fluctuations in provinces.

The government shall strengthen the supporting services to the private sectors through creating a better business environment, more efficient and fair. First, illegal acts by government officials should be cracked down on immediately. Legislation and regulations relating to private business such as registrations/permission for business, tax system, market fees and etc. should be clearly made known to the public to reduce the chances for illegal fee collections. As emerging Traders Associations grow, there might be possibilities for price-fixing arrangements in the market. A supervisory system by government to secure fair competition shall be necessary in future. 


\section{REFERENCES}

Department of Planning, Statistics and International Cooperation, Ministry of Agriculture, Forestry and Fisheries 2004 Agricultural Statistics 2003-2004 Statistics(Agricultural Productivity Improvement Project ITC Credit No110-KH and IFAD Loan 423-KH). Department of Planning, Statistics and International Cooperation, Ministry of Agriculture, Forestry and Fisheries, Phnone Penh, Cambodia

Ministry of Commerce and Ministry of Agriculture, Forestry and Fisheries 2001 Study on improvement of Marketing System and Post harvest Quality Control of Rice in Cambodia. Final Report (Main Report) No 024 AFA, JR, pp. 01-36

The Ministry of Agriculture, Forestry and Fisheries 2004 Agricultural Market Information. Agricultural Marketing Office, Department of Planning, Statistics and International Cooperation, Ministry of Agriculture, Forestry and Fisheries, Phunone Penh, Cambodia

The Royal Government of Cambodia and Japan International Cooperation Agency 2004 The Feasibility Study on Establishment of Open Paddy Market in Cambodia. Interim Report (1) 